\title{
Oxidative stress as a factor in the deterioration of oxygen transfer during exercise
}

\author{
L.M. Gunina ${ }^{1}$, I.L. Rybina ${ }^{2}$, Yu.A. Ataman ${ }^{3}$, V.L. Voitenko ${ }^{4}$ \\ ${ }^{1}$ Olympic Institute of National University for Physical Education and Sports of Ukraine, Kyiv, Ukraine; \\ gunina.sport@gmail.com \\ ${ }^{2}$ Complex Scientific Group on Scientific and Methodological Support of Belarusian Biathlon \\ Federation, Minsk, Republic of Belarus; \\ ${ }^{3}$ Scientific and Methodological Center for Sports Medicine of Sumy State University, Ukraine; \\ ${ }^{4}$ Medical Institute of Sumy State University, Ukraine
}

\begin{abstract}
Blood oxygen transport regulation by physical activity increase within training dynamics is provided with different mechanisms: from the quantitative and qualitative erythron restructure (including endogenous erythropoietin rise and main erythrocyte index shifts) to change in haemoglobin affinity to oxygen, its heterogeneous structure and blood flow growth as a result of endothelium hyperpolarisation. However, the erythrocyte itself remains a key performer in blood velocity control, due to its structure and functions. This review summarizes the data of modern scientific literature on the characteristics of erythrocytes, which make these cells one of the key links in the oxygen transport system of the blood. The focus on this property of erythrocytes during physical activity is based on the fact that the athlete's muscles must be supplied with enough oxygen to ensure high performance. Specific training and extra-training factors affecting the content of erythrocytes have been determined. The membrane structure is treated as a significant erythrocyte part in determining its deformation and microvascular blood transport. Enzymes associated with the erythrocyte membrane and affecting cell viability and performance are described. Besides, it is stressed on monitoring erythrocyte indices via modern equipment and assessing lipid peroxidation, which leads to disorders in erythrocyte membrane structure and functions.
\end{abstract}

Key words: physical activity; erythrocyte; shape; membrane; blood velocity; blood oxygen transport; lipid peroxidation; microcirculation.

Since August Krogh regarded skeletal muscle need for oxygen $\left(\mathrm{O}_{2}\right)$ as a fundamental physiological process [1], there had been a perspective that the most significant blood functions (in terms of energy supply for muscle contraction) are oxygen transfer to tissues and carbon dioxide move to lungs, substrate delivery to muscles, transport and utilization of metabolites. This is provided by haemoglobin as a transport protein located in erythrocytes, making them a key component in blood oxygen circulation $[2,3]$.

For the last decades, many studies had been focused on clarifying mechanisms of oxygen transfer. Although erythrocyte is only one of the $\mathrm{O}_{2}$ delivery elements, it also plays an essential

(C) L.M. Gunina, I.L. Rybina, Yu.A. Ataman, V.L. Voitenko role in oxygen microvascular distribution and transport to tissues. That is necessary for keeping regular skeletal muscle contraction [4].

However, despite many publications on the erythrocyte's role in the delivery of sportsman's muscles with oxygen, our knowledge in this sphere is still incomplete.

The aim of the work is to form modern ideas about the place and role of the erythrocyte in the oxygen transport system by the working muscles of an athlete in the dynamics of intense physical exertion.

Features of the shape and structure of erythrocyte membranes. Erythrocytes (derived

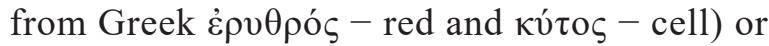
RBC (red blood cells) are non-nuclear cells that 
transfer oxygen to tissues and carbon dioxide reversely. Total erythrocyte content in the blood is equal to cell amount $\cdot 10^{12} \cdot 1^{-1}$ (while among persons with low physical aerobic activity, this number may vary - up to $15-25 \%$ [5-7].

Oxygen transport regulation in case of regular exercise is provided with different mechanisms: from the quantitative and qualitative erythron restructure (including endogenous erythropoietin rise [8] and primary erythrocyte index shifts [6]) to change in hemoglobin ( $\mathrm{Hb})$ affinity to oxygen, its heterogeneous structure [9] and blood flow growth as a result of endothelium hyperpolarisation [10].

Erythrocyte average volume is 76-110 fl. Their shape is a double-concave disc about 7 to $10 \mu \mathrm{m}$ in diameter (Fig. 1). It enlarges their surface, promotes their microcirculation via vessels, increases free oxygen penetration into cells and capillaries.

Prankerd's and further studies showed the erythrocyte double-concave form increases total cell surface by 1.7 times in contrast to that of the ball of the same volume $[11,12]$. As to their size, erythrocytes are divided into normocytes (7.0-8.8 $\mu \mathrm{m}$ in diameter), microcytes (5.5$6.5 \mu \mathrm{m})$ and macrocytes $(8.5-9.0 \mu \mathrm{m})$ [13]. Within the human RBC population, normocytes

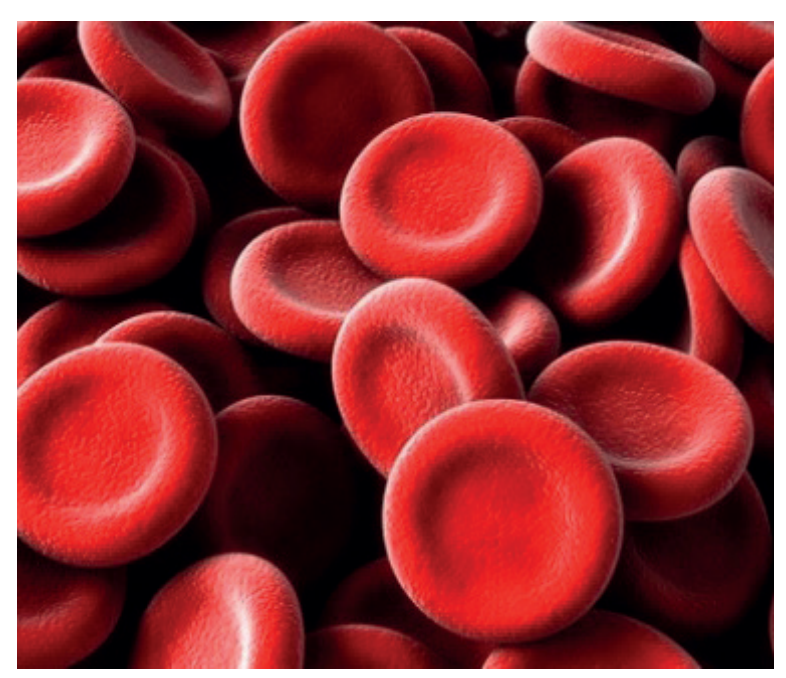

Fig. 1. Erythrocyte shape as a double-concave disc (submicroscopic reconstruction) comprise 85 to $93 \%$, which can be easily seen in optical microscopes (Fig. 2) and this should be a necessary addition to the study of the red blood cell in athletes.

The rise of the total erythrocyte population in micro-and macrocytes (especially when simultaneous deformability falls) may indicate pathologies. For example, microcytes increase by latent iron deficiency and sports anemia (not included in ICD-10 and is a pathological state) caused by iron supply and metabolism $[14,15]$. The same happens in the case of diseases $[13,16]$.

Erythrocytes are cells whose $95 \%$ content is haemoglobin as a spherical tetramolecular protein [17]. Normocytes do not possess a nucleus or other organelles typical for most cells (ribosomes, Golgi apparatus, almost no mitochondria). Still, their structure is maximally adapted to oxygen and carbon dioxide transport, which is exceptionally significant during exercise [18]. For the last decades, biochemists, cell and molecular biologists, physiologists and haematologists have assessed the erythrocyte membrane complexity. In contrast, membrane disorder studies provide valuable information on interactions between its structure and functions. Although RBC membrane disorders provoked by structure and transport change are different, they are often accompanied by anaemia, which significantly slows oxygen transport to tissues in case of physical activity.

The erythrocyte membrane has the ability to deform, as a result of which the erythrocyte can pass through even the narrowest and convoluted microvessels in the tissues of the body and in the pulmonary alveoli, performing the function of gas exchange [19]. The $10 \mathrm{~nm}$ thick erythrocyte membrane is a flexible molecular mosaic of proteins, lipoproteins, glycoproteins and possibly lipids. The membrane is divided into three layers. The outer layer consists of glycoproteins with antigens. The membrane surface is a complex multidimensional structure defined by its inhomogeneity, heterogeneity, and broad protein content. The membrane middle is a lipid bilayer [18]. According to modern 
conceptions, the RBC membrane consists of an approximately equal lipid and protein amount. Membrane lipids are phospholipids or neutral lipids (usually unesterified cholesterin) that are asymmetrically located in the two-molecule thick lipid bilayer. Choline as a phospholipid is situated mainly on the extracellular surface, while aminophospholipid is maximally concentrated on the inner bilayer side. Cholesterin is between phospholipid molecules. The cholesterinphospholipid ratio influences liquid flow via the erythrocyte membrane. If this ratio deviates, morphologically and functionally abnormal RBCs with lower vitality can appear [20]. Lipid molecules are located perpendicular to the plane of the membrane (Fig. 3). Each phospholipid consists of a polar head (molecule hydrophilic part) and two tails (fatty acid residues) [13]. The inner membrane layer consists of glycolytic enzyme proteins, haemoglobin and cytoskeleton proteins [21].

Currently, there is an idea about so-called membrane flippases [22]. Phospholipid flippases are proteins that transfer phospholipids from one membrane to another, even against the composition gradient. Therefore, they can influence the transmembrane asymmetric lipid distribution. Lipid transport produces new membrane structures (in particular, vesicles) connected with different physiological functions in eukaryotic cells - lipid and protein transvesicle carry between organelles or to plasmalemma, liquid-phase endocytosis stimulation.

Lipid transport also launches physiological and biochemical membrane processes: blood clotting, apoptotic or old cell recognition and removal, phosphatidylserine-dependent enzyme control. New lipid group membrane exposition via a quick trigger is a specific signal; being recognized, it may cause physiological modifications. Membrane deformation is a mechanism that initiates such an activity. Various flippase functions are induced by cell lipid diversity itself and the protein's ability to recognize specific messaging molecules [20].

Membrane proteins are also asymmetrically oriented in the lipid bilayer. They are divided into three functional sets: structural, catalytic and sensor proteins [23]. Spectrin and ankyrin are two main structural proteins. Together they form a submembrane cytoskeletal net responsible for $\mathrm{RBC}$ viscoelasticity [24, 25]. At least 35 to 40 enzymes are associated with the membrane. They play a vital role in keeping standard erythrocyte structure and functions. Among these enzymes, there are adenosine triphosphatases, anionic transport protein, glyceraldehyde 3-phosphate dehydrogenase, protein kinases, adenylate cyclase and acetylcholinesterase. Most enzymes are tightly bound to the membrane, and their

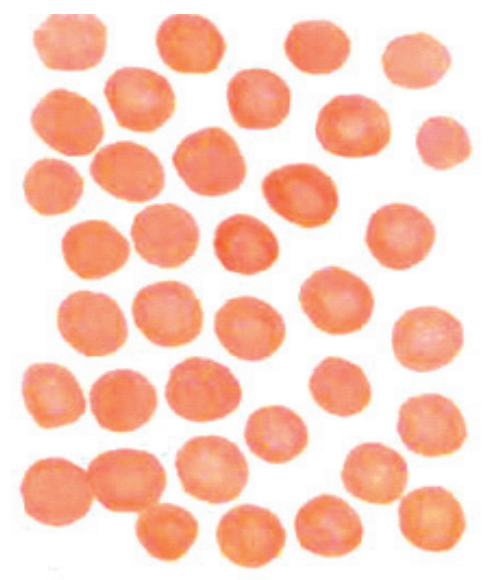

A

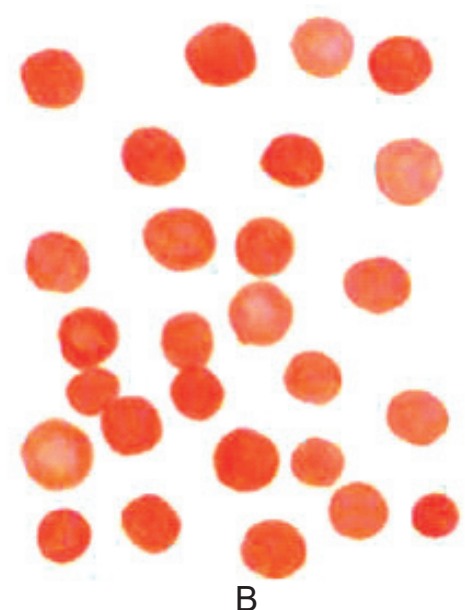

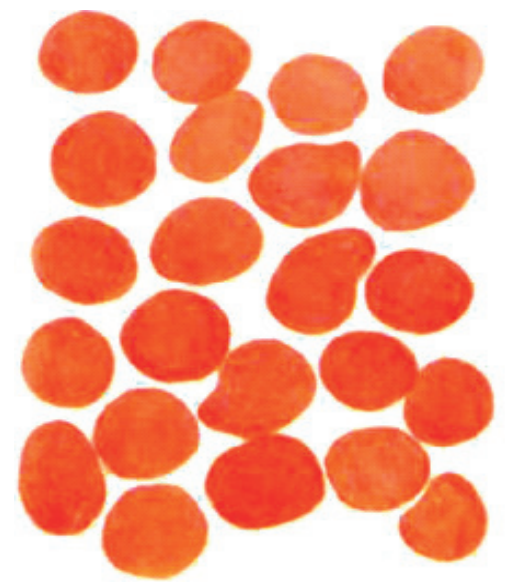

C

Fig. 2. Erythrocyte classification as to size: A - normocytes; B - microcytes; $\mathrm{C}$ - macrocytes 
quantity is small. Adenosine triphosphatases transfer cations actively (those of calcium, sodium and potassium). Anionic transport protein controls chlorine ions, phosphates, glucose and water.

Glyceraldehyde 3-phosphate dehydrogenase gets partially bound to the membrane. Protein kinases catalyze the phosphorylation of several membrane proteins; one of them (spectrin) regulates $\mathrm{RBC}$ mechanical properties. Acetylcholinesterase belongs to ectoenzymes. It is found in erythrocyte plasmalemma (isoform $\mathrm{H}$ anchored in the membrane by fatty acid) [26], although its functions have not been researched entirely so far. It is established that adenylate cyclase activity, $\mathrm{Ca}^{2+}$-dependent, adenosine triphosphatase and phosphorylase changes in various conditions and during diseases (hereditary spherocytosis, sickle cell disease, progressive muscular dystrophy). The same is also detected in the case of strenuous exercise $[27,28]$. Such disorders are caused by low erythrocyte deformability in a sportsman's body [29].

The effect of oxidative stress on erythrocyte transformation during exercise. RBC structure maintenance attracts many researchers in sports laboratory diagnostics because haemoglobin saturation and adequate $\mathrm{O}_{2}$ transfer to tissues is the most significant factor of stimulating exercise performance [30]. During strenuous physical activity, when organs and tissues

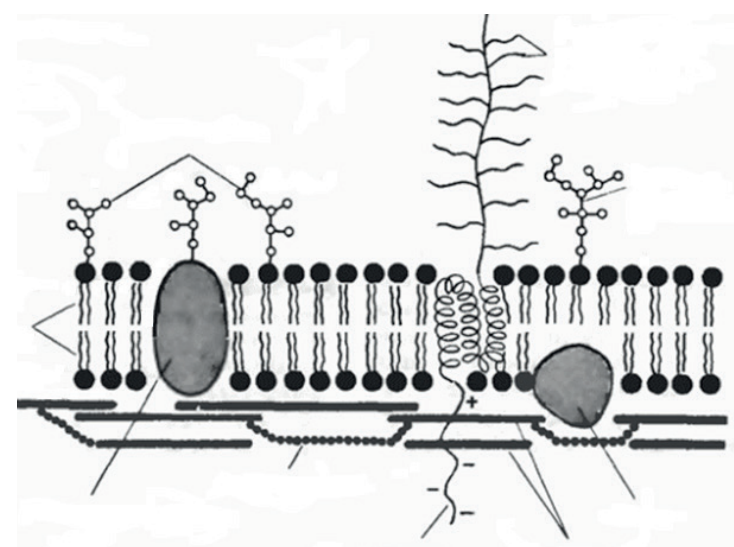

Fig. 3. Erythrocyte membrane structure suffer from hypoxia [31] with a simultaneous increase in peroxidation products [32], there is deviation of cell membrane structure and functions (including those of erythrocytes) [33]. These changes are conditioned by the release of polyunsaturated fatty acids (arachidonic and linoleic ones), as well as leukotrienes, and thromboxane that affect membranes [34]. RBC membrane lipid saturation with omega-3 polyunsaturated fatty acids (contained in specific drugs) improves bilipid membrane structures and shape, raising oxygen transfer $[35,36]$.

Lipid peroxidation with malondialdehyde accumulation, penetrability, and resistance deviation of RBC membrane and shape usually lead to sports anaemia [37-39]. It is membrane denaturation, spectrin and ankyrin degradation, globin reconstruction that is the first negative effect of oxidation stress [40].

In oxidation, extensive lipid and protein degradation (e.g. caused by high drug concentration or super-strenuous exercise) arrange erythrocyte biomolecules, which provokes membrane rigidity. Scanning electron microscopy detects discoid deformation into stomatocytes. Moreover, generalized RBC membrane damage during hyperoxidation induces peculiar modification of the whole cytoskeletal frame as a spread location of spectrin, ankyrin and band 4.1 protein [41]. Since haemoglobin changes, erythrocyte membrane disorder and its pathological transformation are considered by some researchers as a reason for functional sports anaemia [38, 40, 42].

$\mathrm{RBC}$ lipid peroxidation is accompanied by glutathione decrease (one of the main membrane non-enzymatic antioxidants), which also reduces membrane resistance and causes cell lysis. Iron release (chelating deferoxamine) with peroxidating agents produces methemoglobin. Via a scanning electron microscope, one can detect erythrocyte shape damage rise, echinocyte transformation, and appearance of codocytes, stomatocytes, and cnidocyte-like bodies within such circumstances $[43,44]$. These damages are 
more visible in sharp lipid peroxidation and $\mathrm{RBC}$ hemolysis $[45,46]$, which takes place during marathon or triathlon tournaments [47].

Its membrane structural proteins play a significant role in erythrocyte shape change. If cell membrane structure deviates, deformed RBCs may appear. Some of them are shown in Fig. 4. They were obtained during long-term researches of ukrainian athletes in the National University of Ukraine for Physical Education and Sports.

Sickle-cell disease is also caused by membrane skeletal protein change, namely by slow spectrin-adducin-ankyrin dissociation and subsequent reduced release of free $\alpha$-spectrin [48]. Similar irreversible change of erythrocyte S-transformation is induced by cytoskeleton shifts (deviated duplication of $\alpha$-spectrin sites 20 and 21 and that of $\beta-1$ - and $\beta-2$-spectrin, which occurs during their heteromerization and band 4.1 protein fall in the membrane domain) [49].

The transition from discoid to spherocytes vividly depends on intracellular calcium increase. It also correlates with microvesicle decrease in extracellular liquid and varying sensitivity to hydrolytic phospholipase $\mathrm{A}_{2}[50$, 51]. Phosphatidylcholine content change (a key component of the RBC membrane bilipid layer) affects the discoid-to-echinocyte and discoid-tostomatocyte transitions significantly. The former is detected in double phosphatidylcholine saturation; the latter occurs by its double lack $[52,53]$.

Over-exercise leads to membrane-dependent RBC surface shifts, which is explained by its electrophoretic mobility deviation. Simultaneously, lipid peroxidation considerably rises in erythrocyte membranes; that reflects how critical the occurring changes are for the organism itself. Besides, the cell membrane is modified. It is caused by endogenous catecholamines affecting integral sialic glycoproteins among young sportspeople [54] and highly-skilled ones [55].

RBC shape change (provoked by free radicals due to the donor-to-acceptor cysteine ratio alteration) can be significantly reduced via natural antioxidants that slow lipid peroxidation in erythrocyte membranes [56]. From this perspective, sportswomen are less exposed to acute oxidation stress since estrogens may protect RBCs from over-deformation and pathologies. Erythrocyte shape deviations induced by injuries and hemorrhagic shock are accompanied by lipid peroxidation start. Its intensity is positively determined by estrogen [57].

Scanning electron microscopy reveals that oxidation stress leads to considerable RBC size and shapeshifts. The discoid-to-echinocyte transition is often caused by apoptosis through oxygen excess, ionizing radiation, and other agents producing reactive atomic oxygen, exogenous oxidants, calcium penetration into cytomatrix,
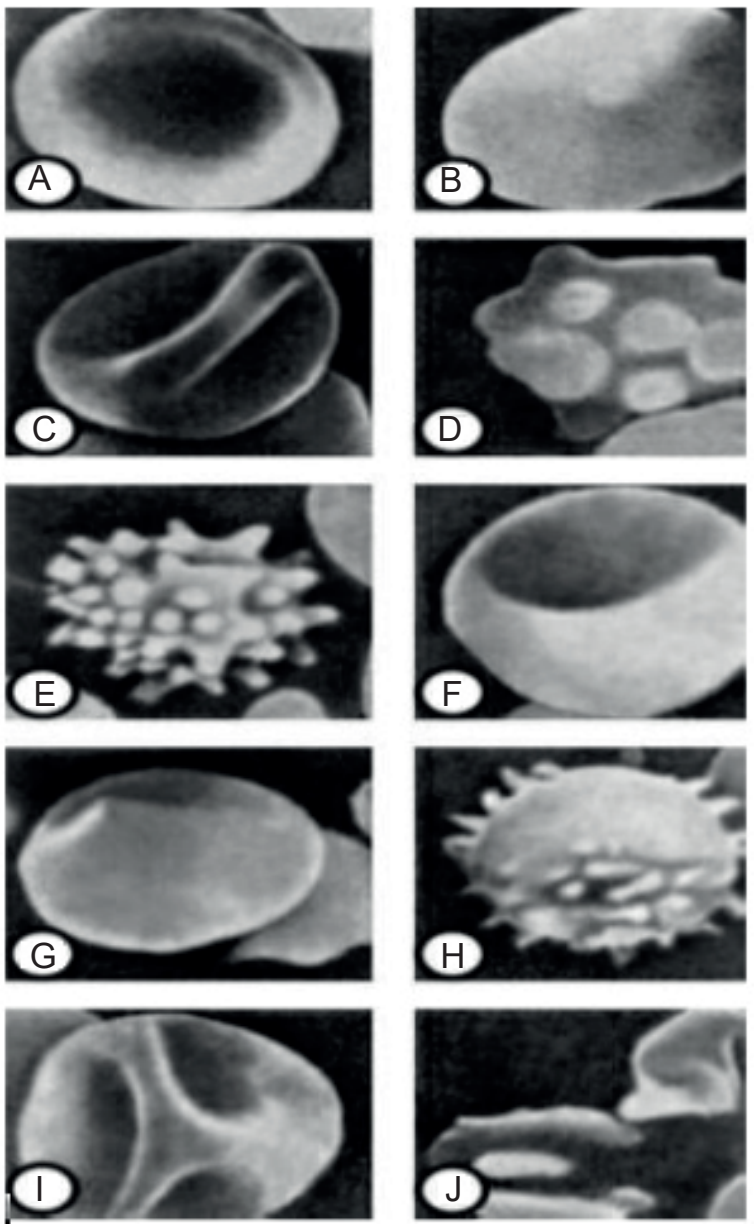

Fig. 4. Deformed erythrocyte types: A - discoid; B, G - planocytes; E - echinocyte; C, F, I - stomatocytes; $\mathrm{H}$ - acanthocyte; D, J - schistocytes 
etc. Biochemical membrane disorders in the case of oxygen-induced echinocytosis can bring to uncontrolled apoptosis via cell shrinkage, lipid peroxidation, energy crisis, and lipid transmembrane asymmetry fall [58].

Factors affecting the transport of oxygen by erythrocytes during exercise. As long as the erythrocyte is alive, its physiological functions can «grow old» [59]. It results in higher membrane penetrability and spherical RBC shape [13]. This prevents cells from moving through fine capillaries, which leads to erythrocyte death with haemoglobin release [60]. Even small, deformed RBC subpopulations significantly affect blood velocity and, subsequently, tissue oxygen saturation in exercise. Moreover, within exercise oxidation stress, deformed RBCs may appear with rigid membranes [61], and haemoglobin viscosity increase [62]. It considerably inhibits oxygen transfer via capillaries and arterioles [63].

Early and late strenuous exercise consequences typical for top sports may reconstruct or even destroy the cell membrane. The first reason for that is product accumulation of membrane oxidative degradation $[64,65]$. Lipid peroxidation effects depend on antioxidant system efficiency. Its two links (enzymatic and non-enzymatic ones) aim to remove and contain lipid peroxidation toxins [66]. That prevents the human body from exercise performance fall and improves after-exercise recovery [61].

RBCs are spawned in marrow from pluripotent stem cells. After differentiation and maturation, they become erythrocytes themselves [67]. RBCs usually exist for about 4 months [68]. Then, they are exposed to regular apoptosis and get destroyed [69].

The main erythropoiesis factor is erythropoietin as a tissue hormone produced in kidneys, liver, and vessel endothelium [70]. Erythropoietin synthesis rises when there is blood oxygen fall (hypoxic stimulus). Erythrocyte amount increase leads to oxygen growth and erythropoietin reduction $[71,72]$. $\mathrm{RBC}$ division and maturation also depend on vitamins $B$ to $B_{12}$ and folic acid [73].
Reference erythrocyte value for healthy adult males is $4.1-5.5 \cdot 10^{12} \cdot 1^{-1}$. For females, it is $3.8-5.1 \cdot 10^{12} \cdot 1^{-1}$. Among sportsmen and sportswomen, RBC content is usually equal to the top reference limit. If aerobic endurance is developed (eg for frequent training), it can exceed that limit $[5,45]$.

Thus, the following factors which affect the change in the content of erythrocytes, as the most important link in the oxygen delivery system, can be distinguished:

I. Sex. Female menstruations may lead to a stable RBC decrease, which affects aerobic capacity.

II. Sports specialization. For cyclic sports with aerobic muscle performance, RBC content is higher.

III. Training peculiarities. Aerobic capacity development raises the erythrocyte amount. Even aerobic exercise for non-cyclic sports (weightlifting) can slightly increase RBCs. However, when hematologic values of speedforce and cyclic sports are interpreted, a specific phase of one year's training should be considered $[6,45]$.

IV. Hypoxic training. Artificial (masks, tents, houses) and natural hypoxia (mountains) induce erythropoietin release and subsequent erythrocyte growth [74]. At the same time, oxygen transfer and aerobic endurance are improved.

V. Diet. Red meat (beef) eaters have a higher RBC value in contrast to vegetarians and vegans.

VI. Dehydration/rehydration degree. During improper liquid loss correction, there may be blood thickening in case of exercise and tournament, and since the content of erythrocytes is a relative value and is measured in $\mathrm{g} \cdot \mathrm{l}^{-1}$, then, naturally, a decrease in the amount of liquid blood fraction leads to an "apparent" increase in the concentration of this indicator.

VII. Drug use. Even legal erythropoiesis stimulators (enhanced biological importance foodstuffs, vitamins $\mathrm{B}-\mathrm{B}_{12}, \mathrm{~A}$ and $\mathrm{C}$ ) raise erythrocyte content correspondingly. However, 
it is illegal for sports to take exogenous erythropoietin or similar drugs [75].

As was mentioned above, mature RBCs do not have nuclei, inner membranes and most organelles. Within erythropoiesis, nuclei leave multipotent progenitor cells [76]. Following erythrocyte features (shape, size and deformability) depend on its membrane. It is prooxidant-antioxidant balance, membrane structure and functions that are a significant addition to automated erythrocytic analysis, which plays a key role in blood oxygen transport. RBCs with undamaged membranes are deformed easily. When $\mathrm{O}_{2}$ falls, ATP release increases. The latter reacts with endothelium purinoceptors and induces local and general vasodilatation. Finally, erythrocytes adapt microvascular perfusion to an accurate oxygen supply to skeletal muscles [77].

Therefore, RBC structure and functions adjust for highly adequate oxygen transfer control (blood velocity, $\mathrm{O}_{2}$ muscle supply). This makes erythrocytes one of the essential components for exercise performance, especially for aerobic endurance. That is why diagnosing, drug use (antioxidants, membrane protective agents, erythropoiesis stimulators permitted by WADA) and hypoxic exercise must be considered in the sports training process.

\section{Л.М. Гуніна ${ }^{1}$, І.Л. Рибіна ${ }^{2}$ Ю.О. Атаман ${ }^{3}$, В.Л. Войтенко ${ }^{4}$ \\ ОКИСНИЙ СТРЕС ЯК ФАКТОР ПОГІРШЕННЯ ПЕРЕНЕСЕННЯ КИСНЮ ПРИ ФІЗИЧНИХ НАВАНТАЖЕННЯХ}

${ }^{1}$ Олімпійський інститут Національного університету фізичного виховання і спорту, Київ, Украӥна; е-таil: gunina.sport@gmail.com;

${ }^{2}$ Комплексна наукова група з науково-методичного забезпечення Білоруської Федерації біатлону, Республіка Білорусь;

${ }^{3}$ Науково-методичний центтр спортивної медицини Сумського держаного університету, Украйна;

${ }^{4}$ Медичний інститут Сумського державного університету, Україна

Регуляція киснетранспортної функції крові при зростанні інтенсивності фізичних навантажень у динаміці тренувального процесу забезпечується механізмами різного рівня: від кількісної та якісної перебудови еритрона, включаючи збільшення вмісту ендогенного еритропоетину та зрушень основних еритроцитарних індексів, до зміни спорідненості до кисню і гетерогенної структури гемоглобіну, а також пришвидшення кровообігу внаслідок гіперполяризації ендотелію. Однак, власне, еритроцит продовжує залишатися в полі зору дослідників як ключова фігура в регуляції швидкості кровообігу, що зумовлено структурно-функціональними характеристиками цієї високоспеціалізованої клітини. В оглядовій роботі узагальнено дані сучасної наукової літератури відносно тих характеристик еритроцитів, які роблять їх однією 3 ключових ланок киснетранспортної системи крові. Увага до цього аспекту властивостей еритроцитів при фізичних навантаженнях базується на потребі адекватного забезпечення працюючих м'язів спортсмена киснем для формування високого рівня фізичної працездатності. Визначено специфічні тренувальні та позатренувальні фактори, що впливають на вміст еритроцитів, розглянута структура еритроцитарної мембрани як найважливішої ланки, котра визначає такі важливі властивості еритроцитів, як здатність до деформації і ефективність переносу кисню по мікросудинах. Приділено увагу ферментам, асоційованим з еритроцитарною мембраною, які значною мірою впливають на життєздатність і функціональну повноцінність еритроцита. Акцент зроблено на необхідності моніторингу еритроцитарних індексів за допомогою сучасної автоматичної апаратури і оцінки вираженості процесів перекисного окиснення ліпідів, що призводить до порушення структурно-функціонального стану мембрани еритроцитів.

Ключові слова: фізичні навантаження; еритроцит; форма; мембрана; швидкість кровообігу; киснетранспортна функція крові; перекисне окиснення ліпідів; мікроциркуляція.

\section{REFERENCES}

1. Krogh A. The respiratory exchange of animals and man. London-New York, Longmans, Green, 1916.

2. Mairbäurl H. Red blood cell function in hypoxia at altitude and exercise. Int J Sports Med. 1994;15(2):51-63.

3. Mairbäurl H, Weber RE. Oxygen transport by hemoglobin. Compr Physiol. 2012;2(2):1463-89.

4. González-Alonso J. ATP as a mediator of erythrocyte-dependent regulation of skeletal muscle blood flow and oxygen delivery in humans. J Physiol. 2012;590(20):5001-13.

5. Gunina L, Rybina I, Kotlyarenko L. Use of indicators of hematological homeostasis to assess the functional state of athletes and control the training process. Sci Olymp Sports. 2020;(3):65-75. [Russian].

6. Ciekot-Sołtysiak M., Kusy K, Podgórski T, Zieliński J. Training-induced annual changes in red blood cell profile in highly-trained endurance and speed-power athletes. J Sports Med Phys Fitnes. 2018;58(12):1859-66.

7. Montero D, Lundby C. Regulation of red blood cell volume with exercise training. Compr Physiol. 2018;9(1):149-64. 
8. Montero D, Breenfeldt-Andersen A, Oberholzer L, Haider T, Goetze Jens P, Meinild-Lundby A-K, Lundby C. Erythropoiesis with endurance training: dynamics and mechanisms. Am J Physiol Regul Integr Comp Physiol. 2017;312(6):R894-R902.

9. Dautova AZ, Khazhieva EA, Shamratova VG. Oxygen transport function of blood at different levels of motor activity depending on polymorphisms of the CMA1 and ACE genes. Modern Probl Sci Educat. 2018;(2). [Russian].

10. Ellis CG, Milkovich S, Goldman. What is the efficiency of ATP signaling from erythrocytes to regulate distribution of $\mathrm{O}_{2}$ supply within the microvasculature? Microcirculation. 2012;19(5):440-50.

11. Prankerd TA. Clinical significance of red-cell structure and metabolism. Br Med J. 1965;2(5469):1017-20.

12. Klenova NA, Klenov RO. The structure, metabolism and functional activity of human erythrocytes in health and disease. Samara, SSU Publ House, 2009;116 p.

13. Moroz VV, Golubev AM, Afanasyev AV, Kuzovlev AN, Sergunova VA, et al. The structure and function of the erythrocyte in normal and critical conditions. General Resuscitat. 2012; VIII (1):52-60. [Russian].

14. Dopsaj V, Martinovic J, Dopsaj M. Early detection of iron deficiency in elite athletes: could microcytic anemia factor (MAF) be useful? Int J Lab Hematol. 2014;36(1):37-44.

15. Malczewska-Lenczowska J, Surała O, Orysiak J, Turowski D, Szczepańska B, Tomaszewski P. Utility of novel hypochromia and microcythemia markers in classifying hematological and iron status in male athletes. Nutrients. 2019;11(11):2767.

16. Charoenkwan P, Taweephol R, Sirichotiyakul S, Tantiprabha W, Sae-Tung R, Suanta S, Sakdasirisathaporn $\mathrm{P}$, Sanguansermsri T. Cord blood screening for alphathalassemia and hemoglobin variants by isoelectric focusing in northern Thai neonates: correlation with genotypes and hematologic parameters. Blood Cells Mol Dis. 2010;45(1):53-7.

17. Longeville S, Stingaciu L-R. Hemoglobin diffusion and the dynamics of oxygen capture by red blood cells. Sci Rep. 2017;7(1):10448.

18. Risinger M, Kalfa TA. Red cell membrane disorders: structure meets function. Blood. 2020;136(11):1250-61.

19. Suzuki Y, Tateishi N, Soutani M, Maeda N. Deformation of erythrocytes in microvessels and glass capillaries: effects of erythrocyte deformability. Microcirculation. 1996;3(1):49-57.

20. Devaux PF, Herrmann A, Ohlwein N, Kozlov MM. How lipid flippases can modulate membrane structure. Biochim Biophys Acta. 2008;1778(7-8):1591-600.

21. Hąc-Wydro K, Dynarowicz-Łątka P. Externalization of phosphatidylserine from inner to outer layer may alter the effect of plant sterols on human erythrocyte membrane the Langmuir monolayer studies. Biochim Biophys Acta. 2012;1818(9):2184-91.

22. Pomorski T, Menon AK. Lipid flippases and their biologi- cal functions. Cell Mol Life Sci. 2006;63(24): 2908-21.

23. Lins L, Decaffmeyer M, Thomas A, Brasseur R. Relationships between the orientation and the structural properties of peptides and their membrane interactions. Biochim Biophys Acta. 2008;1778(7-8):1537-44.

24. Blanc L, Salomao M, Guo X, An X, Gratzer W, Mohandas N. Control of erythrocyte membrane-skeletal cohesion by the spectrin-membrane linkage. Biochemistry. 2010;49(21):4516-23.

25. Chorzalska A, Lach A, Borowik T, Wolny M, HryniewiczJankowska A, Kolondra A, Langner M, Sikorski AF. The effect of the lipid-binding site of the ankyrin-binding domain of erythroid beta-spectrin on the properties of natural membranes and skeletal structures. Cell Mol Biol Lett. 2010;15(3):406-23.

26. Daniels G. Functions of red cell surface proteins. Vox Sanguinis. 2007;93:331-40.

27. Delaunay J. The enzymes of the red blood cell plasma membrane. The enzymes of the red blood cell plasma membrane. Biomedicine. 1977;26(6):357-61.

28. Leonart MS, Nascimento AJ, Nonoyama K, Pelissari $\mathrm{CB}$, Barretto OC. Enzymes and membrane proteins of ADSOL-preserved red blood cells. Sao Paulo Med J. 2000;118(2):41-5.

29. Berzosa C, Gómez-Trullén EM, Piedrafita E, Cebrián I, Martínez-Ballarín E, Miana-Mena FJ, Fuentes-Broto L, García JJ. Erythrocyte membrane fluidity and indices of plasmatic oxidative damage after acute physical exercise in humans. Eur J Appl Physiol. 2011;111(6):1127-33.

30. Gibson JS, Stewart GW, Ellory JC. Effect of dimethyl adipimidate on $\mathrm{K}^{+}$transport and shape change in red blood cells from sickle cell patients. FEBS Lett. 2000;480(2-3):179-83.

31. Revin VV, Gromova NV, Revina ES, Prosnikova KV, Revina NV, Bochkareva SS, Stepushkina OG, Grunyushkin IP, Tairova MR, Incina VI. Effects of polyphenol compounds and nitrogen oxide donors on lipid oxidation, membrane-skeletal proteins, and erythrocyte structure under hypoxia. Biomed Res Int. 2019;2019:6758017.

32. Veiko AG, Sekowski S, Lapshina EA, Wilczewska AZ, Markiewicz KH, Zamaraeva M, Zhao HC, Zavodnik IB. Flavonoids modulate liposomal membrane structure, regulate mitochondrial membrane permeability and prevent erythrocyte oxidative damage. Biochim Biophys Acta Biomembr. 2020;1862(11):183442.

33. Pribush A, Hatskelzon L, Kapelushnik J, Meyerstein N. Osmotic swelling and hole formation in membranes of thalassemic and spherocytic erythrocytes. Blood Cells Mol. Dis. 2003;31(1):43-7.

34. McNamara RK, Welge JA. Meta-analysis of erythrocyte polyunsaturated fatty acid biostatus in bipolar disorder. Bipolar Disord. 2016;18(3):300-6.

35. Judd AM, Best KB, Christensen K, Rodgers GM, Bell JD, et al. Alterations in sensitivity to calcium and enzymatic hydrolysis of membranes from sickle cell disease and trait erythrocytes. Am J Hematol. 2003;72(3):162-69.

36. Giannì ML, Roggero P, Baudry C, Ligneul A, Morniroli 
D, Garbarino F, le Ruyet P, Mosca F. The influence of a formula supplemented with dairy lipids and plant oils on the erythrocyte membrane omega- 3 fatty acid profile in healthy full-term infants: a double-blind randomized controlled trial. BMC Pediatr. 2012;12:164.

37. Robinson Y, Cristancho E, Böning D. Intravascular hemolysis and mean red blood cell age in athletes. Med Sci Sports Exerc. 2006;38(3):480-3.

38. Maciaszek JL, Andemariam B, Huber G, Lykotrafitis G. Epinephrine modulates BCAM/Lu and ICAM-4 expression on the sickle cell trait red blood cell membrane. Biophys J. 2012;102(5):1137-43.

39. Gunina LM. Oxidative stress and adaptation: metabolic aspects of the influence of physical activity. Sci Olympic Sports. 2013;(4):19-25. [Russian].

40. Welbourn EM, Wilson MT, Yusof A, Metodiev MV, Cooper CE. The mechanism of formation, structure and physiological relevance of covalent hemoglobin attachment to the erythrocyte membrane. Free Radic Biol Med. 2017;103:95-106.

41. Yang W, Fu J, Yu M, Huang Q, Wang D, et al. Effects of flaxseed oil on anti-oxidative system and membrane deformation of human peripheral blood erythrocytes in high glucose level. Lipids Health Dis. 2012;11:88.

42. Gunina Larisa, Sergey Konyushok. Antioxidant effect of plant adaptogens on the erythrocyte membranes of weightlifters. Sci Olympic Sports. 2008;(2):111-14. [Russian].

43. Shalev O, Hebbel RP. Catalysis of soluble hemoglobin oxidation by free iron on sickle red cell membranes. Blood. 1996;87(9):3948-52.

44. Snyder LM, Fortier NL, Trainor J, Jacobs J, Leb L, Lubin B, Chiu D, Shohet S, Mohandas N. Effect of hydrogen peroxide exposure on normal human erythrocyte deformability, morphology, surface characteristics, and spectrin-hemoglobin cross-linking. J Clin Invest. 1985;76(5):1971-77.

45. Rybina IL, Gunina LM. Laboratory markers of control and management of the training process of athletes: science and practice. Moscow, Publ House «Sport», 2021; 372 p.

46. Yuksel B. Investigation of morphological abnormalities in red blood cells among dental laboratory technicians. Environ Sci Pollut Res Int. 2021;28(16):20650-58.

47. Machiedo GW, Zaets S, Berezina T, Xu DZ, Spolarics Z, Deitch EA. Red blood cell damage after trauma-hemorrhage is modulated by gender. J Trauma. 2004; 56(4):837-44.

48. Singh M, Sandhir R, Kiran R. Oxidative stress induced by atrazine in rat erythrocytes: mitigating effect of vitamin E. Toxicol Mech Methods. 2010;20(3):119-26.

49. Ajdzanović V, Spasojević I, Filipović B, Sosić-Jurjević B, Sekulić M, Milosević V. Effects of genistein and daidzein on erythrocyte membrane fluidity: an electron paramagnetic resonance study. Can J Physiol Pharmacol. 2010;88(4):497-500.

50. Risso A, Santamaria B, Pistarino E, Cosulich ME, Pompach P, Bezouska K, Antonutto G. Fragmentation of human erythrocyte actin following exposure to hypoxia. Acta Haematol. 2010;123(1):613.
51. Ciccoli L, De Felice C, Paccagnini E, Leoncini S, Pecorelli A, Signorini C, Belmonte G, Guerranti R, Cortelazzo A, Gentile M, Zollo G, Durand T, Valacchi G, Rossi M, Hayek J. Erythrocyte shape abnormalities, membrane oxidative damage, and $\beta$-actin alterations: an unrecognized triad in classical autism. Mediators Inflam. 2013;2013:432616.

52. Butikofer P, Kuypers FA, Lane P, Chiu DT, Lubin BH, Ott P. Erythrocyte phospholipid organization and vesiculation in hereditary high red cell membrane phosphatidylcholine hemolytic anemia. J Lab Clin Med. 1989;113(3):278-84.

53. Robaszkiewicz A, Greig FH, Pitt AR, Spickett CM, Bartosz G, Soszyński M. Effect of phosphatidylcholine chlorohydrins on human erythrocytes. Chem Phys Lipids. 2010;163(7):639-47.

54. Kilic-Toprak E, Ardic F., Erken G, Unver-Kocak F, Kucukatay V, Bor-Kucukatay M. Hemorheological responses to progressive resistance exercise training in healthy young males. Med. Sci. Monit. 2012;18(6):CR351-60.

55. Bizjak DA, Jacko D, Zimmer P, Gehlert S, Bloch W, Grau M. Acute alterations in the hematological and hemorheological profile induced by resistance training and possible implication for microvascular functionality. Microvascul Res. 2018;118:137-43.

56. Maanum G, Jahnsen R, Frøslie KF. Walking ability and predictors of performance on the 6-minute walk test in adults with spastic cerebral palsy. Dev Med Child Neurol. 2010;52(6):126-32.

57. Emmerson O, Bester J, Lindeque BG, Swanepoel AC. The impact of two combined oral contraceptives containing ethinyl estradiol and drospirenone on whole blood clot viscoelasticity and the biophysical and biochemical characteristics of erythrocytes. Microsc Microanal. 2018;24(6):713-28.

58. Yao H, Ma Y, Huang LJ. Deletion of miR-451 curbs JAK2(V617F)-induced erythrocytosis in polycythemia vera by oxidative stress-mediated erythroblast apoptosis and hemolysis. Haematologica. 2020;105(4):e153-56.

59. Lomako VV, Shilo OV. Transformation of erythrocytes in rats of different ages. Advances Gerontol. 2019;32(12):55-9. [Russian].

60. Dinarelli S, Longo G, Dietler G, Francioso A, Mosca L, et al. Erythrocyte's aging in microgravity highlights how environmental stimuli shape metabolism and morphology. Sci Rep. 2018;8(1):5277.

61. Becatti M, Marcucci R, Mannucci A, Gori AM, Giusti B, et al. Erythrocyte membrane fluidity alterations in sudden sensorineural hearing loss patients: The role of oxidative stress. Thromb Haemost. 2017;117(12):2334-45.

62. Tang F, Feng L, Li R, Wang W, Liu H, Yang Q, Ge RL. Inhibition of suicidal erythrocyte death by chronic hypoxia. High Alt Med Biol. 2019;20(2):112-19.

63. Brun JF, Varlet-Marie E, Connes P, Aloulou I. Hemorheological alterations related to training and overtraining. Biorheology. 2010;47(2):95-115.

64. Gunina LM, Orel VE, Savosta AV, Tymchenko AS. Superficial architecture of the cytoskeleton of erythrocytes 
in normal and metabolic changes in the body. Ukr Zh Hematol Transfusiol. 2008;(2):5-13. [Ukrainian].

65. Bolotta A, Battistelli M, Falcieri E, Ghezzo A, Manara $\mathrm{MC}$, et al. Oxidative stress in autistic children alters erythrocyte shape in the absence of quantitative protein alterations and of loss of membrane phospholipid asymmetry. Oxid Med Cell Longev. 2018;2018:6430601.

66. Becatti M, Marcucci R, Gori AM, Mannini L, Grifoni E, Alessandrello LiottaA, Sodi A, Tartaro R, Taddei N, Rizzo S, Prisco D, Abbate R, Fiorillo C. Erythrocyte oxidative stress is associated with cell deformability in patients with retinal vein occlusion. J Thromb Haemost. 2016;14(11):2287-97.

67. Nandakumar SK, Ulirsch JC, Sankaran VG. Advances in understanding erythropoiesis: evolving perspectives. $\mathrm{Br}$ J Haematol. 2016;173(2):206-18.

68. Drüeke TB, Massy ZA. Erythropoiesis-stimulating agents and mortality. J Am Soc Nephrol. 2019;30(6):907-8.

69. Bosman GJ, Willekens FL, Werre JM. Erythrocyte aging: a more than superficial resemblance to apoptosis? Cell Physiol Biochem. 2005;16(1-3):1-8.

70. Sgrò P, Sansone M, Sansone A, Romanelli F, Di Luigi L. Effects of erythropoietin abuse on exercise performance. Phys Sportsmed. 2018;46(1):105-15.

71. Feng S, Chang S, Yan L, Dong H, Xu X, et al. Design, synthesis, and activity evaluation of novel erythro- poietin mimetic peptides. Bioorg Med Chem Lett. 2018;28(18):3038-41.

72. Locatelli Ferrari F, Helal L, Dipp T, Soares D, Soldatelli Â, et al. Intradialytic training in patients with end-stage renal disease: a systematic review and meta-analysis of randomized clinical trials assessing the effects of five different training interventions. J Nephrol. 2020;33(2):251-66.

73. Yan J, Jin G, Du L, Yang Q. Modulation of intestinal folate absorption by erythropoietin in vitro. Mol Pharm. 2014;11(1):358-66.

74. Czuba M, Wilk R, Karpiński J, Chalimoniuk M, Zajac A, Langfort J. Intermittent hypoxic training improves anaerobic performance in competitive swimmers when implemented into a direct competition mesocycle. PLoS One. 2017;12(8):e0180380.

75. Prohibited List-2021 WADA. Electronic resource: https:// www.google.com/search?client=firefox-b-d\&q=wadaama + prohibited + list +2021

76. Ubukawa K, Sawada K. Erythropoiesis and enucleation. Rinsho Ketsueki. 2013;54(7):617-27. (Article in Japan, Summary in English)

77. Sprague RS, Bowles EA, Achilleus D, Ellsworth ML. Erythrocytes as controllers of perfusion distribution in the microvasculature of skeletal muscle. Acta Physiol (Oxf). 2011;202(3):285-92.

Received 26.07.2021 